\title{
Changes in Stress Indicators of Egg-Type Chickens in Response to Different Intensive Housing Systems in Humid Tropics
}

\author{
Olufemi Alabi ${ }^{1}$, Foluke Aderemi ${ }^{1}$, Daniel Afolabi ${ }^{2} \&$ Banwo Alabi $^{3}$ \\ ${ }^{1}$ Department of Animal Science and Fisheries Management, Bowen University, Iwo, Osun-State, Nigeria \\ ${ }^{2}$ Research Outreach Department, Rubber Research Institute of Nigeria, Benin-City, Nigeria \\ ${ }^{3}$ Department of Animal Science, Osun-State University, Ejigbo Campus, Nigeria \\ Correspondence: Olufemi Alabi, Department of Animal Science and Fisheries Management, Bowen University, \\ P.M.B. 284, Iwo, Osun-State, Nigeria. Tel: 234-803-387-1429. E-mail: femiatom@yahoo.com
}

Received: October 8, 2013 Accepted: November 13, 2013 Online Published: March 15, 2014

doi:10.5539/jas.v6n4p151 URL: http://dx.doi.org/10.5539/jas.v6n4p151

\begin{abstract}
Welfare of the animals is of global interest recently and housing of egg-type chickens inside battery cages is being banned in many developed countries in view of the stress to which the chickens are exposed. Measurement of some blood parameters such as White blood cell (WBC) counts and differential leucocytes counts and Heterophil to lymphocyte ratio have been used to assess stress among chickens. Changes in these parameters were therefore investigated among chickens in different housing systems in a typical humid tropical region of the world where animal welfare issue is currently unpopular.108, 17-weeks old Super Black hens (SBL) and 108, 17-weeks old Super Brown hens (SBR) were randomly allotted to three different intensive housing systems of Partitioned Battery Cage (PBC), Extended Battery Cage (EBC) and Deep Litter System (DLS) in a Randomized Complete Block (RCB) design with 36 hens per housing system each with three replicates. The experiment lasted 37 weeks. Parameters measured included Total White Blood cells (WBC), Differential Leukocytes while Heterophil-Lymphocytes ratios $(\mathrm{H} / \mathrm{L})$ were calculated .Data collected were subjected to statistical analysis using 2-way ANOVA while means were separated with Duncan's Multiple Range Test (DMRT). Housing systems had significant effect on the differential leukocyte counts and $\mathrm{H} / \mathrm{L}$ ratios but not on WBC counts. Hens housed inside PBC (control) had the highest values of $\mathrm{H} / \mathrm{L}$ ratio with the least values from those housed on DLS. Meanwhile, the parameters investigated were not significantly affected by the strain. Higher values of $\mathrm{H} / \mathrm{L}$ ratio recorded by hens housed on $\mathrm{PBC}$ which is the conventional system of housing layers in the tropics are indications of stress on the chickens due to lack of freedom to move about and which is against the welfare of the chickens.
\end{abstract}

Keywords: blood, housing, layers, stress, welfare

\section{Introduction}

In spite of the global needs to ensure food security for the ever growing population especially in the tropical and subtropical regions, animal production therefore becomes an inevitable source of protein in human diet. Animal products such as meat, milk and egg are rich sources of animal protein, vitamins and minerals (CAST, 1997) and their inclusion in the diets of people in countries with very low income where the intake is very low presently will definitely improve their health status and level of development. Meanwhile, poultry farming is being widely accepted globally of recent with no restriction as a source of livelihood to the rural sector and employment generation for the upcoming youths and therefore it is of paramount importance (Hasnath, 2002).Performance of laying chickens in terms of egg production, egg qualities and livability is a function of breed, environment and the general routine management practices (Campbell \& Lasley, 1975; Smith, 1995; Alabi et al., 2006), the environmental photoperiods, wind speed and housing. Intensive housing systems such as deep litter and battery cages are commonly used globally. Suto et al. (1997) reported that birds housed inside conventional battery cage had higher hen-day production of eggs than those on free range. However, housing laying hens intensively inside battery cages has received so much opposition recently with the argument that this system poses welfare problems on the birds (Baxter, 1994). According to Nicol (1987), birds housed inside cages are always under stress and will not be able to exhibit some natural behaviors. Animal welfare is an important issue on the European Union agenda (Meghan, 2007), and several countries have been coming up with legislation meant to respond to welfare of the animal (Weibe \& Jupe, 2005). 
While campaign is being made against animal confinement, productivities and profitability on investment on the part of the farmer must also be taken into consideration hence the need to investigate the extent to which birds in cages are being stressed in comparison to other housing systems. In depth reports have been earlier made on stress in livestock production (Chrousos, 1998; Sapolsky, 1999; Sapolsky et al., 2000), but it must be well distinguished from distress and eustress. Stress has been reported to be the deviation from the homeostasis while distress is the metabolic changes that may be unbearable to the animal and eustress is the alteration from metabolic stability as a result of the prevailing condition to which the animal is getting adjusted (Silanikove, 2000).

Various biomedical indices have been relied upon to quantify social, physical and physiological stress. These include the measurement of white blood cell populations, antibody titres, inflammatory response to phyto-hemaglutinin, heart beat rate, serum cortisol and glucose concentrations (Molony et al., 1995), glucocorticoids, epinephrine and norepinephrine concentrations in the blood (Otten et al., 1997). Moreover, reduction in the body and relative spleen weights of chickens has been used to confirm immunological response of birds to stress (Husband, 1993). Also, the concentrations of blood corticosterone have been confirmed to be a good indicator to assess physical stress in birds (Siegel, 1980; Knowles \& Broom, 1990). However, measure of heterophil-lymphocyte ratio of the leukocytes have been suggested to be more reliable for stress quantification in livestock (Molony et al., 1995; Siegel, 1995) and it has been reported that change in the leukocyte concentrations as a result of stress is less variable and therefore a more reliable indicator than plasma corticosterone concentrations ( McFarlane \& Curtis , 1989).

This experiment was therefore designed to investigate changes in the total white blood cell counts, differential leukocytes counts and heterophil-lymphocyte ratios as indicators of stress among two strains of egg-type chickens in three different intensive housing systems in the humid tropics as a mean to justify the need for animal welfare science and ethics in developing countries of the world where the issues of animal welfare is presently uncommon.

\section{Materials and Methods}

\subsection{Location and Animals}

The experiment was carried out at the poultry unit of the Teaching and Research farm of Bowen University, Iwo, Osun-State of Nigeria which is a typical humid zone of tropical Africa. The experimental location lies within the latitude and longitude of $3^{\circ} 52^{\prime} \mathrm{E}$ and $7^{\circ} 23^{\prime} \mathrm{N}$ respectively as described by Olorode (2002). A total of 125 Super Black (SBL) and 125 Super Brown day old chicks were purchased from a reputable farm hatchery located in Oyo-State of Nigeria. They were brooded and reared on deep litter housing system with strict observation of the relevant and welfare specifications. During the first four weeks of age, the chicks were given space allowance of $0.08 \mathrm{~m}^{2}$ per bird (Smith, 1995) and the space got increased with age and at 10 weeks of age it was $0.2 \mathrm{~m}^{2}$ per bird as recommended by Oluyemi and Roberts (2000). During brooding period, the birds were warmed electrically and light-darkness cycle of 23 hours lighting:1 hour darkness was maintained from day old till 56th day of age which was later stepped down to 15 hours lighting : 9 hours darkness from $57^{\text {th }}$ day through 18 week of age as earlier described by Davis et al. (2000).

\subsection{Experimental Design}

At 15 th week of age, 108 pullets were randomly selected from each strain and were divided into three treatment groups of 36 pullets each in a Randomized Complete Block design where the housing system was the treatment that was blocked with strain. Each group of 36 pullets was further divided into three replicates of 12 pullets. The treatment (housing) groups are T1; Partitioned Battery Cage (PBC) which served as the control group being the conventional method of housing egg-type chickens in tropics, T2; Extended Battery Cage (EBC) and T3; Deep Litter System (DLS). EBC shared the same space allowance of $0.1 \mathrm{~m}^{2}$ per bird with PBC (Oluyemi \& Roberts, 2000) but without partitioning to cells to allow birds to move about within the cage. Data collection started at 17 th week of age and lasted 37 weeks.

\subsection{Feed, Feeding and Other Management Practices}

Birds were fed with commercial chicks mash from day old till $8^{\text {th }}$ week of age and thereafter with growers mash till $17^{\text {th }}$ week of age. Layers mash was given to them from $18^{\text {th }}$ till the end of the experiment. Feed and water were given ad libitum while necessary medications and vaccinations were carried out to keep the birds in good health. The proximate composition of the diets given to the experimental birds was determined by the method described by the Association of Official Analytical Chemists (A.O.A.C., 1990).

\subsection{Blood Analysis}

Changes in stress indicators were determined through blood analysis. Blood samples were collected at 17th week of age and bi-weekly thereafter to determine White Blood Cell (WBC) counts and differential leukocytes. $0.3 \mathrm{ml}$ 
of blood was collected via the brachial veins of the bird's wing web into ethylene diamine tetra acetic acid (EDTA-anticoagulant) treated bottles. WBC count was determined with the improved Neubauer haemacytometer method. The Stained-slide method earlier described by Dumonceaux and Harrison (1994) was used to determine the population of various white blood cells (differential leukocytes). Three blood smears were prepared for each sample. They were fixed with methanol and stained immediately with Wright's stain $100 \%$.The smears were later rinsed with distilled water and allowed to air dry under room condition. Leukocyte quantification and classification was done using one hundred cells per slide viewed under oil immersion microscope at 100 times (100x) magnification. Differential leukocytes; Heterophils (H), Lymphocytes (L), Eosinophils (E),Monocytes (M) and Basophils (B) were counted and expressed as percentages of the total leukocytes. The H/L ratio was later calculated for each treatment group (Mitchell et al., 1992).

\subsection{Statistical Analysis}

All data generated were subjected to statistical Analysis of Variance using the package of SAS (2008). The treatment means where significant were separated using Duncan option of the same software. The statistical model employed was:

$$
Y i j=u+B i+T j+E i j
$$

where,

$\mathrm{Yij}=$ individual observation for the ith treatment (housing system) and jth block (strain);

$\mathrm{U}=$ general mean;

$B \mathrm{i}=$ effect of ith treatment;

$\mathrm{Tj}=$ effect of $\mathrm{jth}$ block;

$E \mathrm{ij}=$ experimental error.

\section{Results}

Table 1. Gross composition of grower and layer mash

\begin{tabular}{lcc}
\hline Ingredients & Grower Mash (\%) & Layers Mash (\%) \\
\hline Maize & 42.00 & 49.50 \\
Corn Bran & 10.00 & 0.00 \\
Wheat offal & 17.00 & 10.00 \\
Palm kernel meal (18\%) & 20.00 & 10.00 \\
Groundnut cake & 4.50 & 12.00 \\
Soybean meal (45\%) & 2.00 & 6.00 \\
Fish meal (72\%) & 0.00 & 1.00 \\
Oyster shell & 1.00 & 8.00 \\
Bone meal & 3.00 & 3.00 \\
Salt & 0.25 & 0.25 \\
*Premix & 0.25 & 0.25 \\
Total & $\mathbf{1 0 0 . 0 0}$ & $\mathbf{1 0 0 . 0 0}$ \\
Lysine & 0.10 & 0.10 \\
Methionine & 0.10 & 0.10 \\
Calculated values & & \\
Crude protein (\%) & 13.35 & 16.34 \\
Crude fibre (\%) & 7.20 & 4.65 \\
Ether extract (\%) & 3.75 & 3.50 \\
Calcium (\%) & 0.90 & 3.65 \\
Phosphorus (\%) & 0.45 & 0.48 \\
Metabolizable energy & & \\
(Kcalkg & & \\
\hline
\end{tabular}

*Premix to provide the following per $\mathrm{kg}$ of feed; Vit A-500 iu, Vit D3- $1200 \mathrm{mg}$, Vit.E-11 mg, Vit.K-2 mg, Riboflavin- $20 \mathrm{mg}$, Nicotinic acid- $10 \mathrm{mg}$, Pantothenic acid- $7 \mathrm{mg}$, Cobalamin- $0.08 \mathrm{mg}$, Choline chloride- $900 \mathrm{mg}$, Folic acid- $1.5 \mathrm{mg}$, Biotin- $1.5 \mathrm{mg}$, Iron- $25 \mathrm{mg}$, Manganese- $80 \mathrm{mg}$, Copper-2 mg, Zinc- $50 \mathrm{mg}$, Cobalt- $1.25 \mathrm{mg}$ and Selenium- $0.1 \mathrm{mg}$. 
Table 2. Proximate compositions of grower and layer mash

\begin{tabular}{lll}
\hline Proximate components & Grower Mash (\%) & Layers Mash (\%) \\
\hline Dry matter & 93.60 & 92.50 \\
Crude protein & 14.05 & 16.95 \\
Crude fibre & 7.45 & 4.98 \\
Ether extract & 4.68 & 4.45 \\
Ash & 4.48 & 6.85 \\
Nitrogen Free Extract & 62.94 & 59.27 \\
\hline
\end{tabular}

Table 3. Effect of different intensive housing systems on the white blood cell counts, differential leukocyte counts and $\mathrm{H} / \mathrm{L}$ ratios of egg-type chickens

\begin{tabular}{|c|c|c|c|c|c|}
\hline \multirow[t]{2}{*}{ Parameters } & \multicolumn{5}{|c|}{ Treatments } \\
\hline & Strains & $\mathrm{PBC}$ & $\mathrm{EBC}$ & DLS & Normal Value $(*)$ \\
\hline \multirow[t]{2}{*}{ WBC $\left(10^{3} / u 1\right)$} & SBL & $3.05 \pm 0.01$ & $3.09 \pm 0.008$ & $3.04 \pm 0.01$ & $3.03-21.20$ \\
\hline & SBR & $3.08 \pm 0.01$ & $3.08 \pm 0.009$ & $3.11 \pm 0.01$ & \\
\hline \multirow[t]{2}{*}{ Heterophils (\%) } & SBL & $33.02 \pm 0.96^{\mathrm{a}}$ & $28.10 \pm 0.89^{\mathrm{b}}$ & $25.80 \pm 0.85^{\mathrm{c}}$ & $15.20-32.80$ \\
\hline & SBR & $33.05 \pm 0.96^{\mathrm{a}}$ & $28.00 \pm 0.88^{\mathrm{b}}$ & $25.50 \pm 0.84^{\mathrm{c}}$ & \\
\hline \multirow[t]{2}{*}{ Lymphocytes (\%) } & SBL & $60.05 \pm 3.05^{\mathrm{c}}$ & $65.00 \pm 3.35^{\mathrm{b}}$ & $68.20 \pm 3.55^{\mathrm{a}}$ & $47.20-81.20$ \\
\hline & SBR & $60.00 \pm 3.03^{\mathrm{c}}$ & $65.90 \pm 3.38^{b}$ & $68.00 \pm 3.46^{\mathrm{a}}$ & \\
\hline \multirow[t]{2}{*}{ Monocytes (\%) } & SBL & $3.42 \pm 0.06^{\mathrm{a}}$ & $3.19 \pm 0.03^{c}$ & $3.28 \pm 0.05^{\mathrm{b}}$ & $0.06-0.78$ \\
\hline & SBR & $3.43 \pm 0.06^{\mathrm{a}}$ & $3.20 \pm 0.03^{c}$ & $3.27 \pm 0.05^{\mathrm{b}}$ & \\
\hline \multirow[t]{2}{*}{ Eosinophils (\%) } & SBL & $1.50 \pm 0.03^{\mathrm{a}}$ & $1.31 \pm 0.02^{b}$ & $1.20 \pm 0.02^{c}$ & $6.25-8.25$ \\
\hline & SBR & $1.50 \pm 0.03^{\mathrm{a}}$ & $1.30 \pm 0.02^{\mathrm{b}}$ & $1.21 \pm 0.01^{\mathrm{c}}$ & \\
\hline \multirow[t]{2}{*}{ Basophils (\%) } & SBL & $2.01 \pm 0.03^{\mathrm{a}}$ & $1.60 \pm 0.02^{b}$ & $1.52 \pm 0.008^{\mathrm{c}}$ & $2.50-5.30$ \\
\hline & SBR & $2.02 \pm 0.03^{\mathrm{a}}$ & $1.60 \pm 0.02^{\mathrm{b}}$ & $1.52 \pm 0.008^{\mathrm{c}}$ & \\
\hline \multirow[t]{2}{*}{$\mathrm{H} / \mathrm{L}$ ratio } & SBL & $0.55 \pm 0.008^{\mathrm{a}}$ & $0.43 \pm 0.005^{\mathrm{b}}$ & $0.37 \pm 0.003^{\mathrm{c}}$ & \\
\hline & SBR & $0.55 \pm 0.008^{\mathrm{a}}$ & $0.42 \pm 0.005^{\mathrm{b}}$ & $0.37 \pm 0.003^{\mathrm{c}}$ & \\
\hline
\end{tabular}

$\mathrm{abc}=$ means with different manuscripts along the row are significantly $(\mathrm{P}<0.05)$ different.

Means with no superscript indicate no significant $(\mathrm{P}<0.05)$ difference.

$\mathrm{PBC}=$ Partitioned Battery Cage; $\mathrm{EBC}=$ Extended Battery Cage; DLS $=$ Deep litter System; SBR $=$ Super Black Strain; SBR $=$ Super Brown Strain. * Normal values $=$ Reference Values (in range) for female chickens (Mistruka \& Rawnsley, 1977).

Table 1 shows the gross composition of the diets (grower mash and layers mash) given to the experimental birds. The metabolizable energy and crude protein contents of the diets were formulated to meet the specifications earlier recommended for growing pullets and layers by NRC (1994). Table 2 shows the proximate compositions of the grower and layers mash. The effect of different intensive housing systems on the total White Blood Cell (WBC) counts, differential leukocyte counts and Heterophil / lymphocyte ratios of the two strains of egg-type chickens is 
as shown in Table 3. No significant $(P>0.05)$ difference was observed between the mean values of the WBC of the two strains of bird housed in PBC, EBC and DLS. The mean values ranged from $3.05\left(10^{3} / u l\right)$ for SBL birds on PBC to $3.11\left(10^{3} / u l\right)$ for SBR birds on DLS. The values were within the normal range of 3.03 to $21.20\left(10^{3} / u l\right)$ in the reference values reported by Mistruka and Rawnsley (1977). Differential leukocyte counts were significantly $(P<0.05)$ affected by the housing system only. Heterophil counts of the two strains housed in PBC, EBC and DLS differed significantly $(P<0.05)$ from each other. The range was from $25.80 \%$ (DLS) to $33.02 \%$ (PBC) for SBL strain and $25.50 \%$ (DLS) to $33.05 \%$ (PBC) for SBR strain. The same trend was observed for the eosinophils and basophils counts and also the $\mathrm{H} / \mathrm{L}$ ratios. However, lymphocytes counts of the two strains on PBC, EBC and DLS differed significantly $(P<0.05)$ from each other. The mean values ranged from $60.05 \%$ (PBC) to $68.20 \%$ (DLS) for SBL and $60.00 \%$ (PBC) to $68.00 \%$ (DLS) for SBR. Moreover, birds on PBC had highest values of monocytes counts $(3.42 \%$-SBL and 3.43\%- SBR) while the least values were gotten from birds on EBC (3.19\%-SBL and $3.20 \%$-SBR).

\section{Discussion}

There were absolute differences in the crude protein, crude fiber and ether extract contents of the calculated gross compositions of the grower and layers mash when compared to their proximate values. Although the values were not subjected to statistical analysis, however these differences may be due to the age and source of the feed ingredients and the analytical method used as suggested by Gohi (1980), Tewe and Egbunnike (1992) and Omede (2008). Meanwhile, the proximate compositions were in agreement with the recommendation of NRC (1994) to maintain proper growth and body uniformity of pullets.

As shown in Table 3, the values of the WBC counts were statistically similar for the two strains of chicken housed differently. This is in agreement with the earlier findings of Maxwell (1993) and Neubert et al. (1996) that WBC count is not a reliable mean of assessing stress among chickens but the granulocyte and agranulocyte components. Although, environmental stresses on animals can be revealed through their blood characteristics (Lucas \& Jam, 1961; Orji et al., 1986), however, WBC is more reliable in the measurement of the bird's ability to fight against diseases (Murray et al., 1993) rather than for physical and physiological stress assessments. Therefore, an analysis for differential components of the WBC is necessary for the confirmatory evaluation or assessment of physical and or environmental stress on chickens.

Meanwhile, the values of the heterophil were high with those chickens in PBC with the least values from chickens in EBC. These heterophil cells got elevated in the blood probably in response to the physical stress the birds were exposed to through the housing systems despite the fact that the main role of heterophil cells as being phagocytic is to protect against microbes (Harmon, 1998). Although the period of highest concentration was not established in this work, however, Post et al. (2003) reported that heterophil counts got elevated 24 hours after exogenous administration of corticosterone to broiler chickens and got stabilized thereafter.

Furthermore, chickens on DLS had the highest values of lymphocytes while those on PBC had the least values. Similar results have also been reported on chickens (Ostrowski-Meissner, 1981; Maxwell, 1993). Lymphocytes are widely known to be important in body immune response (Khansari et al., 1990). Also, the result shows that the values of the monocyte which is the largest of all the leukocytes varied among the housing systems. Chickens on PBC had the highest values followed by those on DLS and the least from EBC. This trend may not be linked to the effect of the housing systems.

The basophils and eosinophils have the same trend with the highest values from chickens on PBC and the least from those on EBC. These cells are involved in the regulation of the inflammation response. However, these cells have been reported not to have remarkable indication with stress assessment among chickens (Gross, 1990).

Higher value of $\mathrm{H} / \mathrm{L}$ ratio $(0.55)$ of hens in $\mathrm{PBC}$ as observed showed that they have been exposed to some degree of stress although the immune response was not altered as reflected in the values for the total WBC counts where no significant $(P>0.05)$ difference was observed between the mean values. The $\mathrm{H} / \mathrm{L}$ ratios were increasing from DLS to $\mathrm{EBC}$ and then to $\mathrm{PBC}$ thereby revealing the trend of the increase in the magnitude of the physical stress. This result is in agreement with the reports of Gross and Siegel (1983); Maxwell and Robertson (1998) that hens housed in conventional battery cages had higher circulating non-lymphoid cells (heterophils) than those on free range and therefore are more stressed. Meanwhile ,ratio of the heterophil to lymphocyte can also be increased in birds by factors such as stock density (Gross \& Chickering, 1987), fasting and water deprivation (Hocking et al., 1993).However these blood parameters were not influenced by strain and the interaction between the housing system and the strain. This implies that the blood parameters responded to the housing systems the same way among the two strains of the chicken. Also, it can be inferred that the strains of the chicken has no significant effect on their WBC and the differential leukocyte counts. Meanwhile, the mean values recorded for the monocytes were 
more than the normal value range while those recorded for the eosinophils and basophils were lower than the normal value range earlier reported by Mistruka and Rawnsley (1977) for female chickens, these may be attributed to sampling methods and age of the chickens (Jain, 1986).

\section{Conclusion}

As earlier reported by Dawkins et al. (2004), the housing system adopted for chickens determines the level of welfare given to them rather than the population of the chickens, and therefore must be given thorough investigation in animal welfare science. The need to adopt alternative housing systems for laying chickens must be given global attention. While it is getting established legally in developed countries, there is need to validate this concern in developing countries scientifically. The results of this experiment justify the need to adopt alternative housing systems for egg-type chickens in humid tropics to improve the welfare of the chickens by eliminating the stress from the use of conventional battery cages.

\section{References}

Alabi, O. M., Adejumo, D. O., Aderemi, F. A., Lawal, T. E., \& Ladokun, A. O. (2006). Egg qualities and performance characteristics Of laying chickens in different intensive housing systems. J. of. Agric. Forestry \& Soc. Sc(JOAFSS), 4(1), 160-163.

AOAC. (1990). Association of Official Analytical Chemists. Official methods of Analysis (11th ed.). Washington, D.C

Baxter, M. R. (1994). The welfare problems of laying hens in battery cages. Vet. Rec., 134, 614-619. http://dx.doi.org/10.1136/vr.134.24.614

Campbell, J. A., \& Lasley, J. F. (1975). The science of animals that save humanity (pp. 369-394). USA: Mc Graw Hill Co.

CAST. (1997). Contributions of Animal Products to Healthful Diets. Task force Report No. 131 Council on Agricultural science and Technology, Ames, Iowa.

Chrousos, G. P. (1998) Stressors, Stress and Neuroendocrine Integration of the Adaptive Response: 1997 Hans Selye Memorial Lecture. Ann. NY Acad. Sci., 851, 311-335. http://dx.doi.org/10.1111/j.1749-6632.1998.tb09006.x

Davis, G. S., Anderson, K. E., \& Carroll, A. S. (2000). The effects of long-term caging and molt of single comb white Leghorn hens on Heterophil to lymphocyte ratios, corticosterone and thyroid hormones. Poult. Sci., 79, 514-518. http://dx.doi.org/10.1093/ps/79.4.514

Dawkins, M. S., Donnelly, C. A., \& Jones, T. A. (2004). Chicken Welfare is influenced more by housing conditions than by stocking density. Nature, 427, 342-344. http://dx.doi.org /10.1038/nature02226

Dumonceaux, G., \& Harrison, G. J. (1994). Haematology. In B. W. Ritchie, G. J. Harrison, \& L. R. Harrison (Eds.), Avian Medicine: Principles and Application (pp. 1031-1035). USA: Wingers Publishing, Inc.

Gohi, B. A. (1980). Tropical Feeds. FAO Animal Production and health series (No. 12). Food and Agricultural Organization of United Nations, Rome.

Gross, W. B. (1990). Effect of exposure to a short-duration sound and the stress response of chickens. Avian Dis., 34, 759-761. http://dx.doi.org/10.2307/1591276

Gross, W. B., \& Chickering, W. (1987). Effects of fasting, water deprivation adrenal-blocking chemical on resistance to Escherichia coli challenge. Poultry Sc., 66, 270-272. http://dx._doi.org / 10.3382/ps.0660270

Gross, W. B., \& Siegel, H. S. (1983). Evaluation for the Heterophil-lymphocyte ratio as a measure of stress in chicken. Avian Dis., 27, 972-979. http://dx.doi.org/10.2307/1590198

Harmon, B. G. (1998). Avian heterophils in inflammation and disease resistance. Poultry Sci., 77, 972-977. http://dx.doi.org/10.1093/ps/77.7.972

Hasnath, R. (2002). Effect of feeding systems of the egg production of Fayoumi Hens. Msc Thesis at Department of Animal Science and Animal Health. Royal Vet and Agric. Univ. Bangladesh.

Hocking, P. M., Maxwell, M. H., \& Mitchell, M. A. (1993). Welfare of broiler breeder and layer females subjected to food and water control during rearing. British Poultry Sci., 34, 443-458. http://dx.doi.org/10.1080/00071669308417600

Husband, A. J. (1993). Role of central nervous system and behavior in the immune response. Vaccine, 11, 805-815. http://dx.doi.org/10.1016/0264-410X(93)90355-2 
Jain, W. (1986). Schalm's Veterinary haematology (4th ed., pp. 149-162). Philadelphia: Lea and Febiger.

Khansari, D. N., Murgo, A. J., \& Faith, R. E.(1990). Effects of stress on the immune system. Immunol. Today, 11, 170-175. http://dx.doi.org/10.1016/0167-5699(90)90069-L

Knowles, T. G., \& Broom, D. M. (1990). The handling and transport of broilers and spent hens. Appl. Anim.Behav. Sci., 28, 75-91. http://dx.doi.org/10.1016/0168-1591(90)90047-H

Lucas, A. M., \& Jam, C. C. (1961). Atlas of Avian haematology. US Department of Agriculture.

Maxwell, M. H. (1993). Avian blood leucocyte responses to stress. World's Poultry. Sc. J., 49, 34-43. http://dx.doi.org/10.1079/WPS19930004

Maxwell, M. H., \& Robertson, G. W. (1998). The avian heterophil- leukocyte: a review. World's Poultry. Sc. J., 54(2), 155-178. http://dx.doi.org/10.1079/WPS19980012

McFarlane, J. M., \& Curtis, S. E. (1989). Multiple concurrent stressors in chicks: Effects on plasma corticosterone and Heterophil: lymphocyte ratio. Poultry Sci., 68, 522-527. http://dx.doi.org / 10.3382/ps.0680522

Meghan, S. (2007). EU struggles with broiler welfare legislation. World Poultry Mag., 23(3), 16-17.

Mistruka, B. N., \& Rawnsley, H. M. (1977). Clinical, biochemical and haematological reference values in normal experimental animals. Mason Publishing USA, Inc.

Mitchell, M. A., Kettlewell, P. J., \& Maxwell, M. H. (1992). Indicators of physiological stress in broiler chickens during road transportation. Animal Welfare, 1, 91-103.

Molony, V., Kent, J. E., \& Robertson, I. S. (1995). Assessment of acute and chronic pain after different methods of castration in calves. Appl. Anim. Behav. Sc., 46, 33-48. http://dx.doi.org/10.1016/0168-1591(95)00635-4

Murray, R. K., Granner, D. K., Mayes, P. A., \& Rodwell, V. W. (2000). Harper's Biochemistry (25th eds., pp. 774-776). Stamford Connecticut, USA: Appleton and Lange.

Neubert, E., Gutler, H., \& Valentin, A. O. (1996). Effect of snare restraint on plasma levels of catecholamine, cortisol, insulin and metabolic parameters in growing pigs. Berlin, Munch Tierarztl Washer, 109, 409-413.

Nicol, C. J. (1987). Behavioural response of laying hens following a period of spatial restriction. Anim. Behav., 35, 1709-1719. http://dx.doi.org/10.1016/S0003-3472(87)80063-5

NRC. (1994). National Research Council: Nutrient requirements of Poultry (9th revised ed.). Washington DC: National Academy Press.

Olorode, A. O. (2002). Aerial and land mapping of southwest Nigeria. Ibadan, Nigeria: Spectrum Publishers.

Oluyemi, J. A., \& Roberts, F. A. (2000). Poultry production in warm wet climates. Spectrum books Ltd.

Omede, A. A. (2008). Critical issues in poultry feed quality evaluation in Nigeria. Book of Abstracts and Congress Proceedings, XXIII World's Poultry Congress, 64(2), 455, June $29^{\text {th }}-$ July $4^{\text {th }}, 2008$, Brisbane, Australia.

Orji, B. I., Okeke, G. C., \& Akunyiba, A. O. (1986). Haematological studies on the Guinea Fowl (Numida meleagris pallas). Effect of age, sex and time of bleeding. Nigeria Journal of Animal Production, 13, 94-99.

Ostrowski-Meissner, H. T. (1981). The physiological and biochemical responses of broilers exposed to short-term thermal stress. Comp.Biochem.Physiol., 70A, 1-8. http://dx.doi.org/ 10.1016/0300-9629(81)90383-2

Otten, W., Puppe, B., Stabenow, B., Kanitz, E., Schon, P. C., Brussow, K. P., \& Nurberg, G. (1997). Agonistic interactions and physiological reactions of top and bottom ranking pigs confronted with a familiar and unfamiliar group. Appl. Anim. Behav. Sc., 55, 79-90. http://dx.doi.org/10.1016/S0168-1591(97)00036-1

Post, J., Rebel, J. M., \& Ter Huurne, A. A. (2003). Physiological effects of elevated plasma corticosterone concentrations in broiler chickens. An alternative means by which to assess the physiological effects of stress. Poultry science, 82(8), 1313-1318. http://dx.doi.org/10.1093/ps/82.8.1313

Sapolsky, R. M. (1991). Glucocorticoids, stress and their adverse neurological effect: relevance to ageing. Exp. Gerontol, 34, 721- 732. http://dx.doi.org/10.1016/S0531-5565(99)00047-9

Sapolsky, R. M., Romero, L. M., \& Munck, A. U. (2000). How do glucocorticoids influence stress responses? Integrating permissive, suppressive, stimulatory and preparative actions. Endocrine Rev., 21, 55-89.

SAS. (2008). SAS/STAT 9.2 User's Guide, SAS Institute Inc. Cary, N.C., USA.

Siegel, H. S. (1980). Physiological stress in birds. Bioscience, 301, 529-533. http://dx.doi.org/10.2307/1307973 
Siegel, H. S. (1995). Stress, strains and resistance. British Poultry Sci., 36, 3-22. http://dx.doi.org/10.1080/000716695 08417748

Silanikove, N. (2000). Effect of heat stress on the welfare of extensively managed ruminants. Livest. Prod. Sci., 67, 1-18. http://dx.doi.org/10.1016/S0301-6226(00)00162-7

Smith, A. J. (1995). The Tropical Agriculturists. CTA. London: Macmillan Publisher.

Suto, Z., Horn, P., \& Ujvari, J. (1997). The effect of different housing systems on production and egg quality traits of brown and leghorn type layers. Acta Agraria Kaposvariensis, 1, 29-35.

Tewe, O. O., \& Egbunnike, G. N. (1992). Utilization of cassava in non-ruminant livestock feeds. In R. Hahn \& G. N. Egbunnike (Eds.), Processing cassava as livestock feed in Africa (pp. 28-38).

Weibe, van der S., \& Jupe, S. (2005). Dutch egg producers adapt to changing market. World Poultry Mag., 21(3), 6-10.

\section{Copyrights}

Copyright for this article is retained by the author(s), with first publication rights granted to the journal.

This is an open-access article distributed under the terms and conditions of the Creative Commons Attribution license (http://creativecommons.org/licenses/by/3.0/). 